\title{
The Kinetic Dissolution of Copper from Chalcopyrite-containing Carbonatite Tailings Samples in Sulphate Media
}

\author{
Brad Barlow, Elvis Fosso-Kankeu*, Kolela J Nyembwe, Frans Waanders and Edward Ntumba Malenga
}

\begin{abstract}
The aim of this study was to determine the rate at which $\mathrm{Cu}$ is extracted from the surface of chalcopyrite contained in the tailings from the carbonatitic ore obtained from the carbonate complex in Loolekop, Phalaborwa, South Africa; the rate formation of the passivation phenomena during mineral dissolution was also observed. The objectives of the study, in which the mineral was subjected to sulphate based leaching with ferric sulphate as oxidant were as follows: firstly, to observe the effects of room temperature conditions $\left(25^{\circ} \mathrm{C}\right)$ on the extraction rate of $\mathrm{Cu}$ in the carbonatite tailings system and secondly to determine the effects of mineralogical composition of species within the host ore on the extraction rate and passivation rate formation. The tailings was subjected to X-ray florescence spectroscopy (XRF) for mineralogical characterization as well as $\mathrm{X}$-ray diffraction spectroscopy (XRD) for bulk elemental composition. Phreeqc simulation software was used for the prediction of mineral species using acidity, alkalinity, chloride ion, $\mathrm{pH}$, ORP and sulphate ion as input parameters. The tailings associated with calcite-magnesium, hematite and quartz was prone to acid attack at room temperature conditions during the initial phases of leaching. During the course of the set leaching time, accumulation of gypsum and jarosite occurred, disrupting the transfer of ions from the mineral surface as $5.55 \mathrm{wt} \% \mathrm{Cu}$ extraction was obtained after the leaching period (12 hour) as opposed to the peak extraction rate after 4 hours of leaching $(16.58 \mathrm{wt} \%)$.
\end{abstract}

Index Terms - chalcopyrite, tailings, ferric sulphate media, mineralogy, temperature.

\section{INTRODUCTION}

Leaching copper from low grade chalcopyrite ores are in high demand as other secondary copper sulphides on shallower depth zones are depleting [1], furthermore, chalcopyrite $\left(\mathrm{CuFeS}_{2}\right)$ accounts for $70 \%$ of the world's copper reserves

Elvis Fosso-Kankeu is with the Water Pollution Monitoring and Remediation Initiatives Research Group, School of Chemical and Minerals Engineering, Faculty of Engineering, North-West University, South Africa. Frans Waanders is with the Water Pollution Monitoring and Remediation Initiatives Research Group, School of Chemical and Minerals Engineering, Faculty of Engineering, North-West University, South Africa.

Brad Barlow is with the Water Pollution Monitoring and Remediation Initiatives Research Group, School of Chemical and Minerals Engineering, Faculty of Engineering, North-West University, South Africa.

Kolela $\mathrm{J}$ Nyemba is with the Water Pollution Monitoring and Remediation Initiatives Research Group, School of Chemical and Minerals Engineering, Faculty of Engineering, North-West University, South Africa.

Edward Malenga, School of Mining, Metallurgy and Chemical Engineering, Faculty of Engineering and the Built Environment, University of Johannesburg. further promoting the extraction of copper from this mineral. Pyrometallurgical extraction of copper accounts for $80-85 \%$ of copper extracted from $\mathrm{CuFeS}_{2}$ but is less desired as it causes high sulphur dioxide $\left(\mathrm{SO}_{2}\right)$ emissions [2]; alternatively hydrometallurgical extraction of copper from $\mathrm{CuFeS}_{2}$ also exist which is more cost effective than the former as extraction requires high capital cost smelters and refineries for treatment processes where only small scale leaching plants are required for the latter [3]; better waste management strategies is also characteristic of hydrometallurgical extraction. Despite this hydrometallurgy only accounts for up to $18 \%$ of $\mathrm{Cu}$ production as leaching rates of $\mathrm{CuFeS}_{2}$ are low as a result of a passivation film forming on the surface of the mineral [4][5]. Many studies have focused on identifying the exact cause of the formation of the passivation film but no general accepted theory has been identified as of yet [6][7]. However, some of the most popular theorized mechanisms for the formation of the passivation layer are elemental sulphur enveloping the surface of the mineral, preventing contact of reactants with the mineral surface, metal deficient polysulphides forming on the surface of the mineral and the presence of jarosite which slows leaching kinetics by impeding mass transfer of ions from the mineral surface [8][9][10][11]. Although the exact mechanism for the formation of the passivation film has not been identified, many parameters effecting the recovery rate of copper have been studied and identified. Additive addition, particle size distribution, oxidation redox potential, solution $\mathrm{pH}$ and reaction temperature are but a few of these parameters [12][13][14]. For the purpose of this study the effects of mineralogical composition and solution $\mathrm{pH}$ are considered. Carbonatite tailings from PMC's Rio Tinto mine in Phalaborwa, RSA are used in this study where the highest grade of $\mathrm{Cu}$ ( $1 \%$ copper) is present at the core of the carbonatite complex; carbonatite complexes can be divided into two separate groups, these being alkaline-carbonatites and mineralized carbonatites with the former being of particular interest as they are identified as a noteworthy source of copper [15]. The alkaline-carbonatite complex in Phalaborwa is however geologically unique as it is the only carbonatite complex in the world that is constituted of enough copper sulphide minerals to offer economically feasible operations [16]. The tailings mineralogical composition will differ from the run of mine hoisted from the mine as during flotation of the ROM, phase mutation is said to occur [17]. The effects of the new formed mineral phases on the extraction rate is observed in this study. 


\section{EXPERIMENTAL SETUP AND MODELLING}

\section{A. Materials}

Similar tailings samples as was earlier characterized by Nyembwe et al [18] was used in this study. The samples were provided by the Phalaborwa Mining Company (PMC) and received from their Rio Tinto mine in Phalaborwa, RSA. Through XRF the chemical compositions of the major and trace minerals were exposed as available from Table I; the mineralogical content of the samples is presented in Fig. 1: Diffraction spectrum of tailings mineral

TABLE I: CHEMICAL/ELEMENTAL CHARACTERIZATION OF CARBONATITE TAILINGS MINERAL

\begin{tabular}{cc}
\hline \multicolumn{2}{c}{ Bulk stream chemistry (XRF) } \\
\hline Element & Composition $(\%)$ \\
\hline $\mathrm{Al}$ & 1.63 \\
\hline $\mathrm{Ca}$ & 47.5 \\
\hline $\mathrm{Cu}$ & 0.47 \\
\hline $\mathrm{Fe}$ & 32.6 \\
\hline $\mathrm{Mg}$ & 6.38 \\
\hline $\mathrm{P}$ & 2.47 \\
\hline $\mathrm{Si}$ & 5.18 \\
\hline $\mathrm{Sr}$ & 1.08 \\
\hline
\end{tabular}

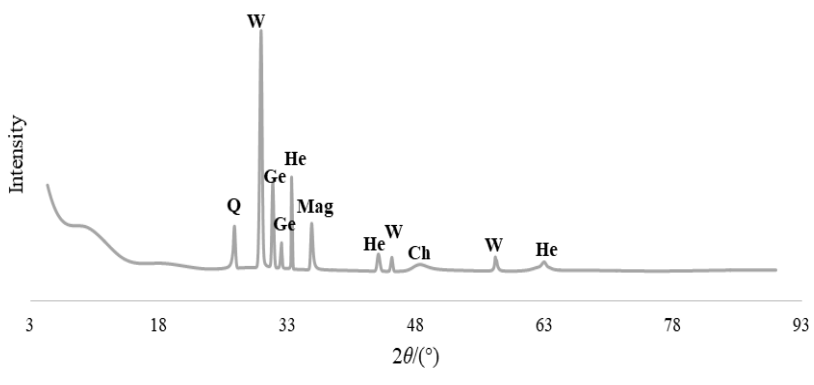

Ch: chalcopyrite (0.47wt \%); Ge: Gehlenite (5.78wt \%) H: hematite (10.07\%); Mag: Magnetite; Q: quartz (12wt \%); W: Calcite magnesium carbonate (73wt $\%)$

Fig. 1: Diffraction spectrum of tailings mineral

\section{B. Chemical leaching}

For the purpose of leaching the carbonatite tailings mineral samples, an incubator with a built in orbital shaker was used. The incubator acted as a containment chamber used to prevent contamination of the solutions during experimentation as well as to keep both the temperature and rotational speed (200 rpm) stable. $500 \mathrm{~mL}$ volumetric flasks were used to prepare a $10 \%$ mass by volume solution; the liquid solution was prepared using distilled water, sulphuric acid and ferric sulphate to produce a ferric sulphate solution of $0.1 \mathrm{M}$ [6]. Rotational speed for the orbital shaker was stable at $200 \mathrm{rpm}$ whilst temperature was set to $25^{\circ} \mathrm{C}$. Each of the solutions was prepared at a $\mathrm{pH}$ value of 0.5-1 after which $\mathrm{pH}$ evolution was allowed to occur over the course of the 12 hours leaching test. The dissolution kinetic information was obtained as $30 \mathrm{~mL}$ sample was withdrawn from the leaching vessel hourly and was analysed for its dissolved metal content using inductively coupled plasma optical emission spectroscopy (ICP-OES). Prior to that, the withdrawn slurry was filtered using $150 \mathrm{~mm}$ filtration paper. Lastly the filtered residue was then dried, stored in a desiccator and were subjected to mineralogical and chemical characterization using $\mathrm{X}$-ray diffraction (XRD) and X-ray fluorescence (XRF) as previously described [19-40].

\section{Leachate analyses}

Leachate samples obtained after leaching chalcopyrite solutions were characterized by measuring $\mathrm{pH}$, oxidation redox potential (ORP) and temperature. For the measurements of $\mathrm{pH}$, temperature and ORP (for each leachate solution) a portable $\mathrm{pH}$ meter with an analytical electrode HI8424 (Hanna Instruments Inc.) was used. Samples were also measured for acidity, alkalinity, chloride ion concentration, sulphate ion concentration. For sulphate ion measurements, a COD and Multiparameter Photometer HI 83099 was used.

\section{Titration tests}

The alkalinity was measured through titration method with $0.1 \mathrm{~N}$ sulphuric acid $\left(\mathrm{H}_{2} \mathrm{SO}_{4}\right)$ where the solution was titrated from $\mathrm{pH}$ values lower than 8.3 to 4.5 using an indicator for clear endpoint visibility. The acidity was measured through titration method with $0.02 \mathrm{~N}$ sodium hydroxide $(\mathrm{NaOH})$ where $0.02 \mathrm{~N}$ sodium carbonate $\left(\mathrm{Na}_{2} \mathrm{CO}_{3}\right)$ was used as standardization procedure. For chloride ion concentration, titration was conducted using silver nitrate $\left(\mathrm{AgNO}_{3}\right)$ and potassium dichromate $\left(\mathrm{K}_{2} \mathrm{CrO}_{4}\right)$ as indicator [41].

\section{E. Speciation modelling}

To determine the aqueous speciation of the major metal ions in the leachate of the carbonatitic tailings, AQUACHEM software was used interfaced with PHREEQC (program version 3.3.12-12704.) modelling software [5][41]. The phreeqc database, Minteq.v4.dat was used for the purpose of this report. The ORP had to be adjusted with a correction factor before it could be used as input data. The correction factor was obtained from Field Measurements of Oxidation-Reduction Potential [42]. The corrected ORP value was then used to calculate the pe value using the following equation:

$$
\mathrm{pe}=\mathrm{E} \_\mathrm{h} /(0.059)
$$

pe donates the negative logarithm of the electron activity.

Eh donates the oxidation redox potential of the sample.

To predict the speciation of the major metals present within the leachate of the chalcopyrite bearing minerals the following input data was used within the phreeqc workbench interface: Acidity, alkalinity, $\mathrm{pH}$, pe, temperature $\left({ }^{\circ} \mathrm{C}\right.$ ), ICP data (metal ion concentrations), $\mathrm{Cl}^{-}$and $\mathrm{SO}_{4}{ }^{2-}$.

\section{RESULTS \& DISCUSSION}

\section{A. $p H$ variation}

Fig. 2: pH behavior of tailings samples at varying time 
displays the $\mathrm{pH}$ evolution of the carbonatite tailings samples at room temperature conditions:

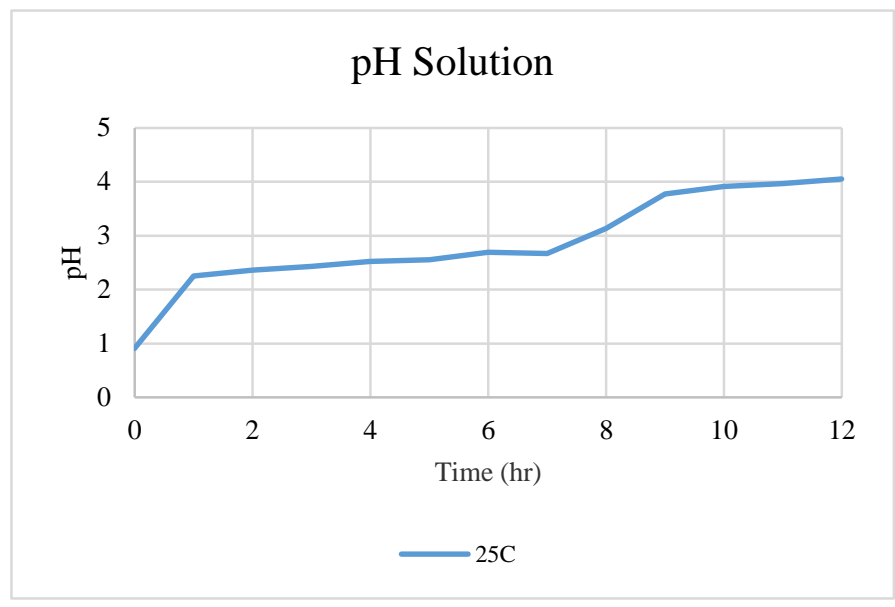

Fig. 2: $\mathrm{pH}$ behavior of tailings samples at varying time

The evolution during experimentation under room temperature conditions $\left(25^{\circ} \mathrm{C}\right)$ was generally acidic but observed to gradually increase during the set leaching time as higher concentration of $\mathrm{Ca}$ is released in solution. The tailings is mainly constituted of calcite magnesium (Fig. 1: Diffraction spectrum of tailings mineral

); $\mathrm{Ca}$ is used to reduce soil acidity as $\mathrm{Ca}^{2+}$ ions reduce $\mathrm{H}^{+}$ ions in solution which neutralized the solution $\mathrm{pH}$ [43]. The same effect are assumed to occur during mineral dissolution as the high Ca content (Table I) releases $\mathrm{Ca}^{2+}$ ions leading to the observed $\mathrm{pH}$ evolution phenomena. Acid attack plays a vital role during the early stages of leaching at room temperature conditions as the formation of calcium salt $\left(\mathrm{CaSO}_{4}\right)$ is believed to occur due to the high $\mathrm{H}_{2} \mathrm{SO}_{4}$ concentrations at these conditions [44]. Insoluble salt species of $\mathrm{Ca}$ is therefore likely the dominant mineral species at the early stages of leaching (first 4 hours) which aids in stabilizing acidic conditions.

\section{B. Extraction behavior at room temperature}

Fig. 3 displays the recovery rate of $\mathrm{Cu}$ and Fe during leaching in sulphate solution using ferric sulphate. After the set leaching time of 12 hours, extraction rate of $5.55 \% \mathrm{Cu}$ from the mineral surface was obtained. Rapid $\mathrm{Cu}$ withdrawal was observed during the first 2 hours of leaching which can be attributed to the acidic $\mathrm{pH}$ conditions observed at this time, where the effects of acid attack on $\mathrm{Ca}$ in solution are the highest. The peak extraction rate of $16.58 \%$ was observed after 4 hours dissolution as the $\mathrm{pH}$ conditions were favorable at this time; this agrees with previous findings according to which the dissolution of $\mathrm{CuFeS}_{2}$ is identified as an acid consuming reaction [45]. The recovery of $\mathrm{Cu}$ is reduced after 6 hours dissolution with increasing $\mathrm{pH}$ conditions likely due to higher concentration of $\mathrm{Ca}^{2+}$ ions cumulating in solution. From the graph no plateau stage is observed indicating that, although the rate of mineral dissolution displays retarding behavior, mineral passivation has not yet been reached.

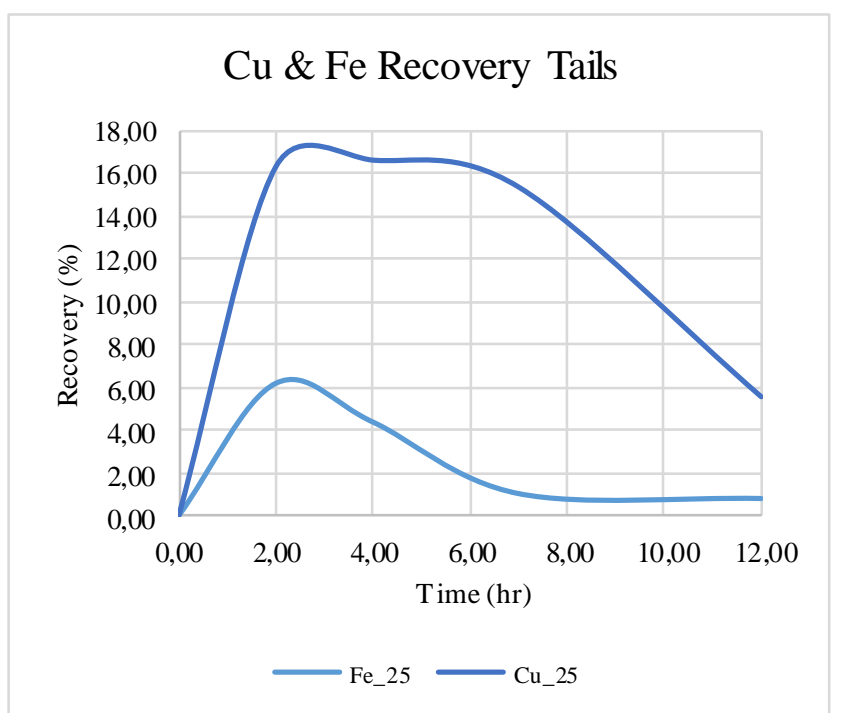

Fig. 3: Recovery of $\mathrm{Cu} \& \mathrm{Fe}$ during mineral dissolution

Fe extraction was also influenced by an increase in the $\mathrm{pH}$ conditions. Fe displays similar behavior to that of $\mathrm{Cu}$ indicating that during acid attack of hematite (the main constituent of $\mathrm{Fe}$ in the carbonatite tails solutions), Fe is more likely to form ferrous iron $\left(\mathrm{Fe}^{2+}\right)$. From previous studies it was observed that $\mathrm{Fe}$ is preferentially released in solution [46] before $\mathrm{Cu}$ as $\mathrm{Fe}^{2+}$ ions compete with $\mathrm{Cu}^{2+}$ ions; competition of $\mathrm{Cu}$ with $\mathrm{Fe}$ could reduce the concentration of soluble species in solution which contributes to the observed extraction behavior.

\section{Speciation results}

Table II displays the speciation results for the tailings samples obtained using phreeqc simulation software and were accurately predicted within a $10 \%$ error threshold:

TABLE II: CARBONATITE TAILINGS STREAM SPECIATION RESULTS

\begin{tabular}{llcccc}
\hline Element & Species & \multicolumn{5}{c}{ Carbonate tailings (\%) } \\
\cline { 3 - 6 } & & $120 \mathrm{~min}$ & $240 \mathrm{~min}$ & $420 \mathrm{~min}$ & $720 \mathrm{~min}$ \\
\hline $\boldsymbol{C a} \boldsymbol{a}$ & $\mathrm{CaSO}_{4}$ & 53.28 & 52.00 & 50.42 & 50.52 \\
\cline { 2 - 6 } & $\mathrm{Ca}^{2+}$ & 46.74 & 48.03 & 49.61 & 49.46 \\
\cline { 2 - 6 } & $\mathrm{CaOH}^{+}$ & $<1$ & $<1$ & $<1$ & $<1$ \\
\hline \multirow{3}{*}{$\boldsymbol{u}(2)$} & $\mathrm{CuSO}_{4}$ & 50.73 & 50.59 & 52.16 & 53.43 \\
\cline { 2 - 6 } & $\mathrm{Cu}^{2+}$ & 49.27 & 49.41 & 47.87 & 46.55 \\
\cline { 2 - 6 } & $\mathrm{CuOH}^{+}$ & $<1$ & $<1$ & $<1$ & 1 \\
\hline \multirow{2}{*}{$\boldsymbol{e}(2)$} & $\mathrm{Fe}^{2+}$ & 70.34 & 69.43 & 68.23 & 67.61 \\
\cline { 2 - 6 } & $\mathrm{FeSO}_{4}$ & 29.66 & 30.59 & 31.77 & 32.39 \\
\cline { 2 - 6 } & $\mathrm{FeHCO}_{3}$ & $<1$ & $<1$ & $<1$ & $<1$ \\
& + & & & & \\
\hline
\end{tabular}

As seen from Table II, a reduction in the formation of calcium salt species $\left(\mathrm{CaSO}_{4}\right)$ along with an increase in calcium ion $\left(\mathrm{Ca}^{2+}\right)$ occurs over the course of the leaching period (12 hours), evident from the $\mathrm{pH}$ evolution behavior (Fig. 2) as higher concentrations of $\mathrm{Ca}^{2+}$ free hydrated ionic species compete with hydrogen ion to stabilize solution $\mathrm{pH}$ [46]. The 
speciation data for $\mathrm{Cu}$ species also agree with the observed recovery behavior (Fig. 3) where the highest concentration of soluble free hydrated cupric ions $\left(\mathrm{Cu}^{2+}\right)$ were the greatest after 4 hours of leaching and observed to reduce as leaching progressed; additionally an increase in insoluble Cu salt species $\left(\mathrm{CuSO}_{4}\right)$ were promoted as leaching progressed together with an increase in $\mathrm{pH}$ conditions. Higher concentrations of soluble ferrous ion $\left(\mathrm{Fe}^{2+}\right)$ species was available but identified as reducing in concentration over the set leaching time as higher concentrations of insoluble $\mathrm{Fe}$ salts $\left(\mathrm{FeSO}_{4}\right)$ formed

\section{Mineralogical investigation of solid residue}

The mineral content for the tailings residue samples for the complete leaching period at room temperature conditions is displayed in Fig. 4 with mineral content summarized in Table III:

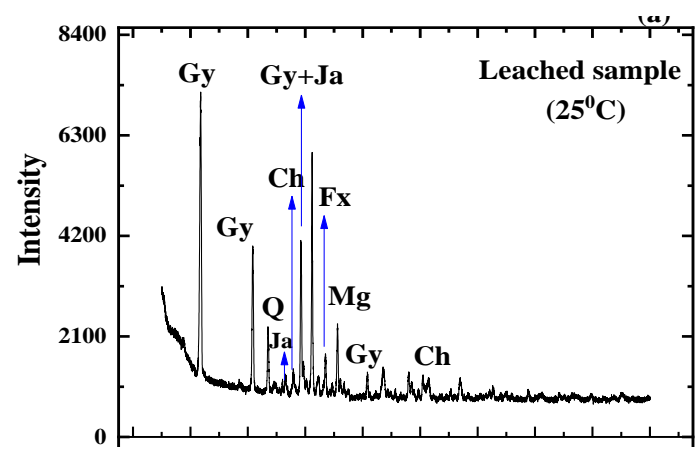

Fig. 4: Diffraction spectrum of tailings residue at $25^{\circ} \mathrm{C}$

Progressive dissolution of the $\mathrm{CuFeS}_{2}$ mineral from the carbonatite tailings host ore was observed for the measured temperature conditions as a decrease in major peak intensity was observed from the initial feed indicating that mineral dissolution had occurred [47][52]. Additionally, new mineral phase formation of $\mathrm{Cu}$ species was identified during the course of the leaching period; these intermediate phases being bornite, chalcocite and covelite. Iron mineral phases of hematite $(\mathrm{He})$, magnetite $(\mathrm{Mg})$ and jarosite $(\mathrm{Ja})$, linked to the dissolution media, were also formed during chemical leaching of the tailings mineral; furthermore, precipitates of gypsum, associated with the carbonatite hosting ore, was also observed.

TABLE III: MINERAL COMPOSITION OF CARBONATITE TAILINGS RESIDUE SAMPLES

\begin{tabular}{cccc}
\hline $\begin{array}{c}\text { Mineral } \\
\text { phase }\end{array}$ & $\begin{array}{c}\text { Chemical } \\
\text { composition }\end{array}$ & \multicolumn{2}{c}{$\begin{array}{c}\text { Mineral } \\
\text { Concentration } \\
(\%)\end{array}$} \\
\cline { 3 - 4 } & & $\mathbf{2 5}{ }^{\circ} \mathrm{C}$ & Feed \\
\hline $\mathbf{B o}$ & $\mathrm{Cu}_{5} \mathrm{FeS}_{4}$ & 0,09 & $* * *$ \\
\hline $\mathbf{C h}$ & $\mathrm{CuFeS}_{2}$ & 0,58 & 0.88 \\
\hline $\mathbf{C x}$ & $\mathrm{Cu}_{2} \mathrm{~S}$ & 0,29 & $* * *$ \\
\hline $\mathbf{C o}$ & $\mathrm{CuS}$ & 0,90 & $* * *$ \\
\hline $\mathbf{G y}$ & $\mathrm{CaSO}_{4} \cdot 2 \mathrm{H}_{2} \mathrm{O}$ & 63,30 & $* * *$ \\
\hline $\mathbf{H e}$ & $\mathrm{Fe}_{2} \mathrm{O}_{3}$ & 1,06 & 10.4 \\
\hline $\mathbf{J a}$ & $\mathrm{XFe}_{3}^{3+}\left(\mathrm{OH}_{6}\left(\mathrm{SO}_{4}\right)_{2}\right.$ & 4,96 & $* * *$ \\
\hline $\mathbf{M g}$ & $\mathrm{Fe}_{3} \mathrm{O}_{4}$ & 10,78 & $* * *$ \\
\hline $\mathbf{Q}$ & $\mathrm{SiO}_{2}$ & 16,99 & 12.00 \\
\hline \multicolumn{7}{c}{}
\end{tabular}

\section{CONCLUSION}

The purpose of this study was to observe the dissolution kinetics of the tailings stream minerals with particular focus on the effects of mineralogical composition of the new formed phases from concentration of the Rom material on the leaching kinetics. The major compositional mineral (calcite-magnesium [73wt\%]) from the host ore had a big impact on the leaching kinetics as the speciation prediction showed an increase in free hydrated calcium ion $\left(\mathrm{Ca}^{2+}\right)$ which reduced the solution acidity as these ions compete with $\mathrm{H}^{+}$for dissolution. As concentration of Ca increases, the formation of gypsum at these conditions are further promoted. The reduction in potential and increase in $\mathrm{pH}$ also further promoted the formations of ferric salt species during the course of the set leaching period. At these conditions, the dissolution of $\mathrm{Cu}$ could be hindered as the surface of the mineral is enclosed by a matrix mixture of gypsum and jarosite that impedes the transfer of ions from the surface of the mineral.

\section{ACKNOWLEDGEMENTS}

The authors are thankful to the support from the North-West University, and the laboratory assistance of Mr N Lemmer from the North-West University as well as Ms N Baloyi from the University of Johannesburg.

\section{REFERENCES}

[1] J. Schaming, "An Investigation of Leaching Chalcopyrite Ores," Kingston, 2011.

[2] M. Sokic, B. Markovic and D. Zivkovic, "Kinetics of chalcopyirte leaching by sodium nitrat in sulphuric acid," Hydrometallurgy, no. 95, pp. 273-279, 2009.

https://doi.org/10.1016/j.hydromet.2008.06.012

[3] M. Khoshkhoo, "Chalcopyrite Disolution in Sulphate-Based Leaching and Bioleacging Systems," 2014.

[4] M. Stott, H. Wattling and P. Franzmann, "The role of iron-hydroxy precipitates in the passivation of chalcopyrite during bioleaching," Minerals Engineering, vol. 13, no. 10, pp. 1117-1127, 2000.

https://doi.org/10.1016/S0892-6875(00)00095-9

[5] B. Barlow, K. Nyembwe, E. Fosso-Kankeu and F. Wanders, "Prediction of Dissolution of Copper from a Chalcopyrite Carbonatite Ore of South Africa," CapeTown, 2018.

[6] E. Cordoba, J. Munoz, M. Blazquez and A. Ballester, "Leaching of chalcopyrite with ferric opn Part I: General Aspects," Hydrometallurgy, no. 93, pp. 81-87, 2008. https://doi.org/10.1016/j.hydromet.2008.04.015

[7] Y. Li, N. Kawashima, J. Li, A. Chandra and A. Gerson, "A Review of the Structure, Fundamental Mechanisms and Kinetcis of the Leaching of Chalcopyrite," 2013

https://doi.org/10.1016/j.cis.2013.03.004

[8] Biegler, I. \& Swift, D., 1979. Anodic electrochemistry of chalcopyrite. Journal of Applied Electrochemistry, Volume 9, pp. 545-554. https://doi.org/10.1007/BF00610940

[9] Peterson, J. \& Dixon, D., 2006. Competitive bioleaching of pyrite and chalcopyrite. Hydrometallurgy, Issue 83, pp. 40-49. https://doi.org/10.1016/j.hydromet.2006.03.036

[10] Gomez, C. et al., 1996. Electrochemistry of chalcopyrite. Hydrometallurgy, Volume 43, pp. 331-344. https://doi.org/10.1016/0304-386X(96)00010-2

[11] Tshilombo, A., 2004. Mechanism and kinetics of chalcopyrite passivation and depassivation during ferric and microbial leaching, s.l.: s.n.

[12] Hackl, R., Dreisinger, D., Peters, E. \& King, J., 1995. Passivation of chalcopyrite during oxidative leaching in sulfate media. Hydrometallurgy, Issue 39, pp. 25-48.

https://doi.org/10.1016/0304-386X(95)00023-A 
[13] Antonijevic, M. \& Bogdanovic, G., 2004. Investigation of the leaching of chalcopyrite ore in acidic solutions. Hydrometallurgy, Volume 73, pp. 245-256. https://doi.org/10.1016/j.hydromet.2003.11.003

[14] Acero, P., J.Cama, Ayora, C. \& Asta, M., 2009. Chalcopyrite dissolution rate law from $\mathrm{pH} 1$ to 3. Geologica Acta, 7(3), pp. 389-397.

[15] Simandl, G. \& Paradis, S., 2018. Carbonatites: related ore deposits, resources, footprint, and exploration methods. Applied Earth Science, 127(4), pp. 123-152. https://doi.org/10.1080/25726838.2018.1516935

[16] Heinrich, E., 1970. The Phalaborwa Carbonatitic Complex: A Unique Copper Deposit, s.l.: s.n.

[17] V. Gorbachev, V. Abzalov and B. Yur'ev, "Conversion of magnetite to hematite in iron-ore pellets," Steel in Translation, vol. 37, p. 27, 2007. https://doi.org/10.3103/S0967091207040031

[18] K. Nyembwe, E. Fosso-Kankeu, F. Waanders and K. Nyembwe, "Structural, composition and mineralogical characterization of carbonatitic copper sulfide: Run of mine, concentrate and tailings," International Journal of Minerals, Metallurgy and Materials, vol. 26, no. 2, pp. 143-151, 2019. https://doi.org/10.1007/s12613-019-1718-8

[19] Fosso-Kankeu E., Potgieter J. and Waanders F.B. 2019. Removal of malachite green and toluidine blue dyes from aqueous solution using a clay-biochar composite of bentonite and sweet sorghum bagasse. International Journal of Applied Engineering Research. 14(6): 1324-1333.

[20] Johannes Cornelius van der Linde, Elvis Fosso-Kankeu, Gerhard Gericke, Frans Waanders, Louise Dreyer, Nico Lemmer. 2019. Flocculant types and operating conditions influencing particles settling rates in feed water used at a coal power plant. Desalination and Water Treatment. 150: 293-300. https://doi.org/10.5004/dwt.2019.23735

[21] Assumpta Chinwe Nwanya, Miranda M. Ndipingwi, Noluthando Mayedwaa, LC Razanamahandry, Chinwe O Ikpo, Tesfaye Waryo, SKO Ntwampe, E Malenga, E Fosso-Kankeu, Fabian I Ezema, Emmanuel I Iwuoha, Malik Maaza. 2019. Maize (Zea mays L.) fresh husk mediated biosynthesis of copper oxides: Potentials for pseudo capacitive energy storage. Electrochimica Acta. 301: 436-448 https://doi.org/10.1016/j.electacta.2019.01.186

[22] LC Razanamahandry, CT Onwordi, W Saban, AKH Bashir, L Mekuto, E Malenga, E Manikandan, E Fosso-Kankeu, M Maaza, SKO Ntwampe. 2019. Performance of various cyanide degrading bacteria on the biodegradation of free cyanide in water. Journal of Hazardous Materials. 380: $1-6$ https://doi.org/10.1016/j.jhazmat.2019.120900

[23] E. Fosso-Kankeu, A. Mulaba-Bafubiandi, B.B. Mamba, T.G. Barnard, Assessing the effectiveness of a biological recovery of nickel from tailings dumps. Journal of Minerals Engineering. Vol. 24, pp. 470-472, 2011 https://doi.org/10.1016/j.mineng.2010.11.007

[24] E. Fosso-Kankeu, T.L. Netshitanini, A.L.K. Abia, E. Ubomba-Jaswa, F.B. Waanders, Application of solar treatment for the disinfection of geophagic clays from markets and mining sites. African Journal of Biotechnology. Vol. 14, no. 50, pp. 3313-3324, 2015. https://doi.org/10.5897/AJB2015.14971

[25] E. Fosso-Kankeu, F. Waanders, C.L. Fourie, Adsorption of Congo Red by surfactant-impregnated bentonite clay. Desalination and Water Treatment. doi: 10.1080/19443994.2016.1177599: pp. 1-9, 2016.

[26] A.H. Munyai, E. Fosso-Kankeu, F. Waanders, Biological influence on the mobility of metals from mine tailing dump located in Krugersdorp area. International Journal of Science and Research. ISSN: 2319-7064. Vol. 5, no. 4, pp. 1396-1403, 2016. https://doi.org/10.21275/v5i4.NOV162808

[27] T.L. Netshitanini, E. Fosso-Kankeu, F. Waanders, E. Ubomba-Joswa, A.L.K. Abia, Co-effect of leached metals and $\mathrm{pH}$ of simulated gastric fluid on the survival of microorganisms in geophagic clays. International Journal of Science and Research. ISSN: 2319-7064. Vol. 5, no. 4, pp. 1107-1116, 2016. https://doi.org/10.21275/v5i4.NOV162696

[28] E. Fosso-Kankeu, F. Waanders, M. Geldenhuys, Impact of nanoparticles shape and dye property on the photocatalytic degradation activity of
TiO2. International Journal of Science and Research. Vol. 5 , no. 11, pp. $528-535,2016$

[29] A.H. Munyai, E. Fosso-Kankeu, F. Waanders, Mobility of metals from mine tailings using different types of organic acids: Batch leaching experiment. International Journal of Science and Research. Vol. 5, pp. 520-527, 2016.

[30] E. Fosso-Kankeu, A. Manyatshe, F. Waanders, Mobility potential of metals in acid mine drainage occurring in the Highveld area of Mpumalanga Province in South Africa: Implication of sediments and efflorescent crusts. International Biodeterioration and Biodegradation. Vol. 119, pp. 661-670, 2017. https://doi.org/10.1016/j.ibiod.2016.09.018

[31] E. Fosso-Kankeu, F.B. Waanders, F.W. Steyn, Removal of Cr(VI) and $\mathrm{Zn}$ (II) from an aqueous solution using an organic-inorganic composite of bentonite-biochar-hematite. Desalination and Water Treatment. Vol. 59, pp. 144-153, 2017. https://doi.org/10.5004/dwt.2017.0059

[32] E. Fosso-Kankeu, F. Waanders, A.F. Mulaba-Bafubiandi and S. Sidu, Leachability of suspended particles in mine water and risk of water contamination. $10^{\text {th }}$ ICARD/IMWA 2015; $10^{\text {th }}$ International Conference on Acid Rock Drainage \& IMWA Annual Conference. 21-24 April 2015 Santiago-Chile. Editors: Adrian Brown, Charles Bucknam, Joanna Burgess, Manuel Carballo, Devin Castendyk, Linda Figueroa, Lisa Kirk, Virginia McLemore, James McPhee, Mike O'Kane, Robert Seal, Jacques Wiertz, David Williams, Ward Wilson, Christian Wolkersdorfer. ISBN: 978-956-9393-28-0. Chap 4. Pp 1-9. 2015.

[33] E. Fosso-Kankeu, F.B. Waanders, and A.H. Munyai, Susceptibility of Metals Release from Tailings Dumps Located In the Krugersdorp Area. $7^{\text {th }}$ International Conference on Latest Trends in Engineering and Technology (ICLTET' 2015), November 26-27, 2015 Irene, Pretoria (South Africa). Editors: E. Muzenda and T Yingthawornsuk. ISBN: 978-93-84422-58-5. 2015.

[34] E. Fosso-Kankeu, F. Waanders, and C. Laurette Fourie, Surfactant Impregnated Bentonite Clay for the Adsorption of Anionic Dyes. $7^{\text {th }}$ International Conference on Latest Trends in Engineering and Technology (ICLTET' 2015), November 26-27, 2015 Irene, Pretoria (South Africa). Editors: E. Muzenda and T Yingthawornsuk. ISBN: 978-93-84422-58-5. 2015.

[35] E. Fosso-Kankeu, F.B. Waanders, F.W. Steyn, The Preparation and Characterization of Clay-Biochar Composites for the Removal of Metal Pollutants. $7^{\text {th }}$ International Conference on Latest Trends in Engineering and Technology (ICLTET' 2015), November 26-27, 2015 Irene, Pretoria (South Africa). Editors: E. Muzenda and T Yingthawornsuk. ISBN: 978-93-84422-58-5. 2015.

[36] E. Fosso-Kankeu, F. Waanders, and M. Geldenhuys, Photocatalytic Degradation of Dyes using $\mathrm{TiO}_{2}$ Nanoparticles of Different Shapes. $7^{\text {th }}$ International Conference on Latest Trends in Engineering and Technology (ICLTET' 2015), November 26-27, 2015 Irene, Pretoria (South Africa). Award Winning Paper. Editors: E. Muzenda and T Yingthawornsuk. ISBN: 978-93-84422-58-5. 2015.

[37] E. Fosso-Kankeu, F. Waanders, T.L. Netshitanini, E. Ubomba-Jaswa, and K. Abia, Identification of Metals in Geophagic Clays: Investigation of their Behaviour in Simulated Gastric Fluid. $7^{\text {th }}$ International Conference on Latest Trends in Engineering and Technology (ICLTET' 2015), November 26-27, 2015 Irene, Pretoria (South Africa). Editors: E. Muzenda and T Yingthawornsuk. ISBN: 978-93-84422-58-5. 2015.

[38] E. Fosso-Kankeu, F. Waanders, and W. Botes, Recovery of Base Metals from Mine Tailings Dumps collected in the Vicinity of Potchefstroom: Leaching assisted by Complexing Agent. $7^{\text {th }}$ International Conference on Latest Trends in Engineering and Technology (ICLTET' 2015), November 26-27, 2015 Irene, Pretoria (South Africa). Editors: E. Muzenda and T Yingthawornsuk. ISBN: 978-93-84422-58-5. 2015.

[39] Elvis Fosso-Kankeu, Charl Olivier, Dumisane Moyakhe, Brad Barlow, Quentin Campbell and Frans Waanders. 2018. Effect of fine coal tailing porosity on the mobility and speciation of heavy metals in the leachates. Editors: Elvis Fosso-Kankeu, Frans Waansders, Michel Plaisent. 10th Int'l Conference on Advances in Science, Engineering, Technology \& Healthcare (ASETH-18) Nov. 19-20, 2018 Cape Town (South Africa). ISBN: 978-81-938365-2-1. Vol I. Pp 101-105.

[40] Fosso-Kankeu Elvis and Redelinghuys Johannes. 2018. Bacterial ecology of biofilms sustaining pollution by acid mine drainage near mining areas in Mpumalanga Province - South Africa. $11^{\text {th }}$ ICARD/IMWA/MWD 
Conference "Risk to Opportunity". 10-14 September 2018 Pretoria, South Africa. C. Wolkersdorfer, L. Sartz, A. Weber, J. Burgess, G. Tremblay.ISBN: 978-0-620-80650-3 Vol 1 (2 volumes).

[41] B. Barlow, E. Fosso-Kankeu, N. Lemmer and F. Waanders, "Geochemical Speciation of Metal ions in the Leachate of Tailings Treated with Synthetic Rain Water," Parys, 2017

[42] B. Stiggov, "Field Measurements of Oxidation-Reduction Potential (ORP)," 2013.

[43] J. E. Lamar, "Uses of Limestone and Dolomite," Urbana, 1961.

[44] K. Scrivener, "Calcium Aluminate Cemenets," in Lea's Chemistry of Cement and Concrete, 1998, pp. 713-782. https://doi.org/10.1016/B978-075066256-7/50025-4

[45] P. Acero, J.Cama, C. Ayora and M. Asta, "Chalcopyrite dissolution rate law from pH 1 to 3," Geologica Acta, vol. 7, no. 3, pp. 389-397, 2009.

[46] D. Lu, W. Wang, Y. Chang, F. Xie and K. Jiang, "Thermodynamic Analysis of Possible Chalcopyrite Dissolution Meachanism in Sulphuric Acidic Aqueous Solution," Metals, vol. 6, p. 303, 2016 https://doi.org/10.3390/met6120303

[47] A. Santos, F. Arena, A. Benedetti and D. Bevilaqua, "Effect of redox potential on chalcopyrite dissolution imposed by addition of ferrous ions," Ecletica Quimica Journal, vol. 42, pp. 40-50, 2017. https://doi.org/10.26850/1678-4618eqj.v42.1.2017.p40-50

[48] A. Manyatshe, E. Fosso-Kankeu, D. van der Berg, N. Lemmer, F. Waanders, H. Tutu, Metal retention potential of sediment and water quality in the Mooi River, South Africa. Desalination and Water Treatment. doi: 10.5004/dwt2017.20222. 2017.

[49] A. Manyatshe, E. Fosso-Kankeu, D. van der Berg, N. Lemmer, F. Waanders, H. Tutu, Dispersion of inorganic contaminants in surface water in the vicinity of Potchefstroom. Physics and Chemistry of the Earth. Vol. 100, pp. 86-93, 2017. https://doi.org/10.1016/j.pce.2017.04.008

[50] A. Manyatshe, E. Fosso-Kankeu, D. van der Berg, N. Lemmer, F. Waanders, H. Tutu, Metal speciation in the rivers around Potchefstroom based on seasonality. Water Environment Research. Vol. 90, no. 1, pp. $84-95,2018$ https://doi.org/10.2175/106143017X15054988926587

[51] A. Manyatshe, E. Fosso-Kankeu, D. Van Der Berg, N. Lemmer, F. Waanders, H. Tutu, Assessment of seasonal variation in surface water quality of the Mooi and Vaal Rivers network, South Africa. International Conference on Advances in Science, Engineering, Technology and Natural Resources (ICASETNR-16) Nov. 24-25, 2016, Parys - South Africa. ISBN: 978-93-84468-79-8. 2016.

[52] K. Nyembwe, E. Fosso-Kankeu, F. Wanders and E. Malenga, "Mineralogical observation made during the kinetic dissolution study of chalcopyrite mineral in sulphate media under free $\mathrm{pH}$ at room temperature," Cape Town, 2018 